\title{
LEADERSHIP STYLE AND ITS RELATION TO EMPLOYEE ATTITUDES AND BEHAVIOUR
}

\author{
CHERYL MESTER \\ DELÉNE VISSER \\ GERT ROODT \\ Programme in Industrial Psychology \\ Department of Human Resource Management \\ Rand Afrikaans University \\ RITA KELLERMAN \\ RSM, Erasmus University \\ Rotterdam
}

\begin{abstract}
The purpose of this study was to determine the relationships between leadership style and organisational commitment, job satisfaction, job involvement and organisational citizenship behaviour and whether these relationships were stronger for transformational than for transactional leaders. A sample of 52 leaders and 276 raters from a world class engineering company participated. The results of a canonical correlation analysis using the rater data indicated that the most prominent relationship was that between transactional leadership and affective commitment. Furthermore, transformational and transactional leadership did not correlate significantly with the constructs of job involvement and job satisfaction.
\end{abstract}

\section{OPSOMMING}

Die doel van die ondersoek was om te bepaal wat die verbande tussen leierskapstyl en organisasieverbondenheid, werkstevredenheid, werkbetrokkenheid en organisatoriese burgerskapsgedrag is en of hierdie verbande sterker is vir transformasionele as vir transaksionele leiers. 'n Steekproef van 52 leiers en 276 beoordelaars van 'n wêreldklas ingenieursfirma het deelgeneem. Die resultate van 'n kanoniese korrelasie-ontleding van die beoordelaardata het getoon dat die prominentste verband dié tussen transaksionele leierskap en affektiewe verbondenheid is. Verder het transformasionele en transaksionele leierskap nie beduidend met die konstrukte werkbetrokkenheid en werkstevredenheid gekorreleer nie.

Organisations and managers are increasingly aware that they face a future of rapid and complex change. This wave of futureoriented uncertainty, coupled with individual demands for increased participation at all levels of the organisation, has dramatically changed perceptions of leadership, specifically with regard to the respective roles played by the leader and the follower. Almost all leadership theory is based on the relative importance assigned to the leader versus the follower in mission accomplishment. However one questions what effect this has on employee attitude and behaviour. Although there are many factors affecting employee attitudes and behaviour, research to date implies that these are influenced to some extent by leadership style. In an attempt to understand leadership effectiveness, researchers have studied two main lines of theory. Transformational leadership, which has emerged as a dominant approach, is contrasted in many studies to transactional leadership. Both transformational and transactional leaders are active leaders who actively intervene to solve and prevent problems from occurring. Numerous studies have also compared these two styles of leadership to laissez faire leadership, which is descriptive of an inactive leader (Barbuto, 1997; Hartog \& Van Muijen, 1997; Hater \& Bass, 1988; Posdakoff, MacKenzie \& Bommer, 1996; Tepper \& Percy, 1994; Tracey \& Hinkin, 1998; Trott \& Windsor, 1999).

Leadership theory suggests a positive relation between transformational/transactional leadership and other constructs such as organisational commitment, job involvement, job satisfaction and organisational citizenship behaviour. However, based on the cumulative evidence thus far, one could expect transformational leadership to have a stronger, positive relationship with these constructs. Judge and Bono (2000, p.754) stated, "the MLQ ratings do not include some potentially relevant outcomes, such as organisational commitment or overall job satisfaction. Although one would expect that the subordinates of transformational leaders are more satisfied with

Requests for copies should be addressed to: C Mester, Department of Human Resource Management, RAU University, PO BOX 524, Auckland Park, 2006 their jobs and more committed to their organisations, with a few exceptions,... there is little evidence to support these linkages." Several studies indicate that transformational leadership, when compared to transactional and laissez faire leadership, results in higher levels of satisfaction, commitment, organisational citizenship behaviour, cohesion, motivation, performance, satisfaction with the leader and leader effectiveness (Avolio \& Bass, 1999; Barbuto, 1997; Covin \& Kolenko, 1997; Hartog \& Van Muijen, 1997; Hater \& Bass, 1988; Posdakoff, MacKenzie \& Bommer, 1996; Tepper \& Percy, 1994). Although the attitudes of job satisfaction, job involvement and organisational commitment represent distinct concepts (Brooke, Russel \& Price, 1988), research has indicated that the these work-related variables are likely consequences of each other (Brown, 1996). As a positive emotional state reflecting an affective response to the job situation (job satisfaction), and a cognitive belief state reflecting one's psychological identification with the organisation (job involvement), researchers have indicated that these two attitudes to a specific job are different from one another and from organisational commitment which focuses on the individual's identification with the organisation as a whole (Brooke, Russell \& Price, 1988; Brown, 1996). Trott and Windsor (1999) provided findings that indicate that staff nurses are more satisfied with transformational leaders, and that their level of satisfaction increases as the leader uses a more participative style. Furthermore, Hater and Bass (1988) found transformational leadership to be positively correlated with how effective subordinates perceive leaders, how much effort they say they will expend for the leader, how satisfied they are with the leader, and how well subordinates perform as rated by the leader.

This study aims to determine the relationship between leadership styles and the attitudes and behaviour of organisational commitment, job satisfaction, job involvement and organisational citizenship behaviour. The results of this study would be particularly relevant given the centrality of leadership to the success or failure of organisations. Although there are many differentiations in the leadership theory, there 
appears to be an acceptance of the distinction between transformational, transactional and laissez faire leadership. These will now be discussed.

\section{Transformational Leadership}

Transformational leaders are said to be responsible for motivating employees to go beyond ordinary expectations (Hater \& Bass, 1988). The transformational leader elicits this performance level by appealing to follower's higher order needs and moral values, generating the passion and commitment of followers for the mission and values of the organisation, instilling pride and faith in followers, communicating personal respect, stimulating subordinates intellectually, facilitating creative thinking and inspiring followers to willingly accept challenging goals and a mission or vision of the future (Carless, 1998; Hartog \& Van Muijen, 1997; Posdakoff, MacKenzie \& Bommer, 1996; Tepper \& Percy, 1994; Tracey \& Hinkin, 1998; Trott \& Windsor, 1999). The leader thus identifies the future of the organisation and "pulls, rather than pushes" (Trott \& Windsor, 1999, p. 128), lifting individuals to focus their commitment and energies towards the organisation and its goals (Barbuto, 1997).

Transformational leadership theorists suspect that a consequence of the transformational leader's behaviour is the emotional attachment to the leader and emotional and motivational arousal of followers. The degree to which a leader is regarded as being transformational depends on the effect he or she has on the follower, where followers of transformational leaders feel trust and respect towards leaders, and are motivated to perform extraordinary behaviours (Barbuto, 1997).

Research to date indicates that transformational leadership behaviours exist in all levels of management and in a variety of organisational settings and are therefore not limited to executives and world-class leaders (Hater \& Bass, 1988). In a study assessing the link between leader personality and transformational leadership behaviour, Judge and Bono (2000) found that by controlling for transactional leadership, transformational leadership behaviour significantly predicted subordinate satisfaction with the leader, subordinate organisational commitment, work motivation and supervisory ratings of leader effectiveness. No relationship was however found with subordinate overall job satisfaction.

It is apparent in the literature that four dimensions underlie the transformational leadership construct (Barbuto, 1997; Bass \& Avolio, 1997; Bass \& Steidlmeier, 1998; Hartog \& Van Muijen, 1997; Tracey \& Hinkin, 1998), namely:

- Charismatic leadership or idealised influence: the leader instills pride and faith in followers, provides a vision and a sense of mission, gains respect and trust and sets high standards for emulation;

- Inspirational leadership: the leader inspires followers to accept challenging goals, provides meaning for engaging in shared goals and arouses team spirit through enthusiasm and optimism.

- Individualised consideration: the leader recognises individual uniqueness, links the individuals' current needs to the organisation's needs and provides coaching, mentoring and growth opportunities;

- Intellectual stimulation: the leader encourages followers to approach problems in new ways and to creatively think of new ways to carry out their daily responsibilities.

\section{Transactional Leadership}

Whereas transformational leaders motivate subordinates to perform beyond expectations, transactional leadership is based on the traditional, bureaucratic authority and legitimacy where followers receive certain valued outcomes when they act according to the leader's wishes. The relationship is based on a series of exchanges or implicit bargains between leader and follower, clarifying role expectations, assignments and task- oriented goals. Transactional leaders thus focus their energies on task completion and compliance and rely on organisational rewards and punishments to influence employee performance (Hartog \& Van Muijen, 1997; Tepper \& Percy, 1994; Tracey \& Hinkin, 1998; Trott \& Windsor, 1999). According to Hater and Bass (1988, p.695) "the dynamics of a quid pro quo dominates the transactional exchange, in which the leader clarifies task requirements and rewards for compliance." Transactional leadership theory rests on the notion that when the environment and the job do not motivate, direct and satisfy the follower, the transactional leader has to rely on his or her behaviours to compensate for the deficiency. The leader clarifies what he or she expects from subordinates regarding acceptable standards of performance and what they will receive in return (Hartog \& Van Muijen, 1997). Transformational and transactional leadership models thus differ with regard to the process by which leaders motivate subordinates and the types of goals set (Hater \& Bass, 1988).

Research on transactional leadership indicates that there are three dimensions underlying the transactional leadership construct (Bass \& Avolio, 1997; Bass \& Steidlmeier, 1998; Hartog \& Van Muijen, 1997; Hater \& Bass, 1988; Tepper \& Percy, 1994):

- Contingent rewards or reinforcement: The leader uses rewards, promises and praise to motivate followers to achieve performance levels contracted by both parties.

- Active management-by-exception: The leader monitors followers' performance, taking corrective action in anticipation of problems or when irregularities occur

- Passive management-by exception: The leader waits passively for mistakes to occur, or for things not to go as planned, before taking corrective action with negative feedback or reprimand.

Hater and Bass (1988) indicated that, by contrasting transformational and transactional leadership, it does not mean that the two models are unrelated. In fact, researchers have indicated that, although the two are distinct concepts, they are interrelated, meaning that a leader can be both transactional and transformational. It is argued that transformational leadership builds on transactional leadership and not the other way around. Transformational leadership is thus viewed as an extension of the transactional leadership style (Avolio \& Bass, 1999; Bass \& Steidlmeier, 1998; Hartog \& Van Muijen, 1997). Transactional and transformational leaders are described as such, because at the defining moment their beliefs, attitudes and behaviours resemble that of either the transactional or the transformational leader (Bass \& Steidlmeier, 1998). Bass and Avolio (1997) were of the opinion that, although transformational leadership may be more effective in changing times, the transactional process of clarifying certain expectancies for a reward, is an essential component of the full range of effective leadership.

\section{Non-transactional or Laissez Faire Leadership}

Transactional and transformational leadership, two active forms of leadership, are often contrasted to a passive laissez faire leadership style. As no attempt is made by the laissez faire leader to motivate others or to recognise and satisfy individual needs, researchers have concluded that this leadership style is indicative of an absence of leadership. The laissez faire leader avoids decision-making, the provision of rewards and the provision of positive/negative feedback to subordinates (Bass \& Avolio, 1997; Hartog \& Van Muijen, 1997).

Hater and Bass (1988, p. 697) argued that, "passive managementby-exception is not the same as laissez faire leadership. The status is guarded and respected in passive management-by-exception; the status is ignored by the laissez faire leader who essentially avoids decision making and supervisory responsibilities."

In assessing the relationship between leadership styles and employee commitment attitudes and engagement behaviours, it 
is important to understand the constructs of organisational commitment, job satisfaction, job involvement and organisational citizenship behaviour.

\section{Organisational commitment}

Morrow (1983) indicated that several but different theoretical foundations have been used to define commitment related concepts with a number of measuring instruments as a result. Despite the lack of consensus on the conceptual and theoretical development of this construct, the concept of organisational commitment has attracted considerable interest in an attempt to understand and clarify the intensity and stability of an employee's dedication to the organisation. Researchers have distinguished between three approaches to study commitment, namely from an attitudinal, behavioural and a motivational perspective. Although several studies have viewed affective commitment as an attitude and continuance commitment as a behaviour (Boyle, 1997; McGee \& Ford, 1987; Reichers, 1985; Somers, 1993), Allen and Meyer (1990) recognised that the cost involved in leaving an organisation may be regarded as a psychological state and therefore view continuance commitment as a component of attitudinal commitment. According to Allen and Meyer (1990, p.1), organisational commitment consists of a three-dimensional construct defined as follows:

The affective component of organisational commitment... refers to the employee's emotional attachment to, identification with, and involvement in, the organisation. The continuance component refers to commitment based on the costs that the employee associates with leaving the organisation. Finally, the normative component refers to the employee's feeling of obligation to remain with the organisation.

A number of studies have supported the distinctiveness and independence of these three dimensions and provide evidence that they also have unique antecedents (Allen \& Meyer, 1990; Boyle, 1997; Eisenberger, Fasolo \& Davis-LaMastro, 1990; McGee \& Ford, 1987; Meyer \& Allen, 1984; Meyer, Allen \& Smith, 1993; Randall, Dunham, Grube \& Castaneda, 1994; Reichers, 1985; Shore, Barksdale \& Shore, 1995; Somers, 1993). Furthermore, support has been found for two distinct dimensions of continuance commitment, one based on personal sacrifices involved in leaving the organisation, and the second based on limited employment opportunities (McGee \& Ford, 1987; Randall, Dunham, Grube \& Castaneda, 1994; Somers, 1993).

Although reference to the term 'organisational commitment' describes three very different constructs, a common denominator underlying each construct is the individual's psychological attachment to the organisation, and it is therefore this psychological attachment that defines organisational commitment. The three concepts differ in terms of the link between the employee and the organisation. Employees with a strong affective attachment stay with the organisation because they want to, those with a strong continuance commitment stay because they need to and those with a strong normative commitment stay because they feel they ought to (Allen \& Meyer, 1990; Caldwell, Chatman \& O’Reilly, 1990; Meyer, Allen \& Smith, 1993). Literature indicates that highly committed employees are more satisfied with their work, perform at levels beyond expectation, are more motivated and experience higher levels of job involvement (Boyle, 1997; Caldwell, Chatman \& O'Reilly, 1990; Eisenberger, Fasolo \& Davis-LaMastro, 1990). A large percentage of these studies have been based on employee self report measures of commitment. In an attempt to determine managerial perceptions of employee commitment, research has indicated that organisational citizenship behaviour is predictive of manager-rated affective commitment, and that side bets such as age and tenure are predictive of manager-rated continuance commitment (Shore, Barksdale \& Shore, 1995). Meyer, Allen and Smith (1993) argued however that commitment is a complex and multifaceted construct, and therefore a multidimensional approach should be taken when studying commitment. Research suggests that employees experience several different commitments to the goals and values of multiple groups, and that where two individuals may be committed to 'the organisation', the focus of the two commitments may be entirely different. Individuals may thus be committed in varying degrees to top management, immediate supervisors, peers, customers, unions, their career, occupation or profession (Boyle, 1997; Meyer, Allen \& Smith, 1993; Reichers, 1985). The distinction between different commitment foci may therefore only be of theoretical interest if the same theoretical base is used for operationalising the different foci (Roodt, 1997; Storm \& Roodt, 2002). Lee, Carswell and Allen (2000) for example undertook a study to assess the relationship between occupational commitment and person-and work-related variables. Results of the study indicate that occupational commitment is positively related to organisational commitment as well as job-focused constructs such as job involvement and satisfaction.

\section{Job Satisfaction}

As an attitude, job satisfaction has been extensively researched, and has in many studies been considered a dependent and an independent variable. Agho and Price (1992, p. 185) defined job satisfaction as "the extent to which employees like their work". In investigating job satisfaction, a distinction is usually made between a global feeling of liking one's job in general and a constellation of attitudes about various facets of the job where individuals indicate their satisfaction with parts of their job, such as pay, promotion, work, supervisors and co-workers (Ironson, Smith, Brannick, Gibson \& Paul, 1989; Lease, 1998).

Although research to date has focused specifically on the impact of job satisfaction on commitment, absenteeism and turnover (Agho \& Price, 1992), results of several studies have indicated that employees are more likely to experience job satisfaction when they are able to use their skills and knowledge on the job, perform enriched tasks, the organisation adopts a participative approach to decision-making, employees experience positive employee-management relations, supervisors act considerately towards their workers, the organisation recognises and rewards employee talents, instills the values and principles held by employees and listens to employees (Bailey, 1999; Bassett, 1994; Berg, 1999; Harkins, 1998; Levin \& Stokes, 1989). Additional studies have shown that intrinsic motivation has a positive effect on job satisfaction, as does the role of a subordinate's supervisor (Blau, 1999; Lu, 1999).

A constant debate in the job satisfaction literature is the effect of situational and dispositional mechanisms on attitude formation. Cropanzano, James and Konovsky (1993) for example found that the dispositional mechanisms of positive affectivity (an individual's disposition to be happy across all situations) and negative affectivity (an individual's disposition to experience discomfort) were related to global job satisfaction, whereas Steel and Rentsch (1997, p. 878) found support for both situational and dispositional mechanisms, concluding that one could "view job satisfaction as the product of both person-based tendencies and situation-based experiences".

\section{Job involvement}

Job involvement, as a type of work-related attitude has for a long time been the focus of research. Unfortunately, the concept has not evolved in a logical and evolutionary fashion, resulting in several different theoretical conceptualisations of the construct with a myriad of measuring instruments as a consequence (Bleeker \& Roodt, 2002). Although there appears to be a lack of consensus on the meaning of job involvement, Paullay, Alliger \& Stone-Romero (1994, p. 224) defined job involvement as "the degree to which one is cognitively preoccupied with, engaged in, and concerned with one's present job." This attitudinal construct is often contrasted and viewed as a polar opposite of alienation, where alienation implies a 'state of individuality and separation from the self and work environment'. Alienation is 
said to exist when an individual experiences powerlessness, meaninglessness, normlessness, isolation and self-estrangement (Brown, 1996, p. 235).

In addition to research showing job involvement as a unidimensional construct concerned with an individual's psychological identification (Blau, 1985), Paullay, Alliger and Stone-Romero (1994) found that two distinct constructs are important and necessary to experience job involvement. Job involvement-role, refers to the degree to which one is involved in the specific tasks that make up one's job, and job involvement-setting, refers to the situation where the individual finds the present work environment engaging.

Involvement in a specific job is different from involvement with work in general. The former is concerned with the present job's ability to satisfy one's present salient needs and the latter with the centrality of work in one's life. The extent to which an employee experiences job involvement depends on (a) the saliency of both intrinsic and extrinsic needs and (b) the perception held by the individual of the present job's ability to satisfy these needs (Kanungo, 1982b).

The degree to which the job situation is central to the individual and satisfies one's salient needs is distinct but related to other forms of work-related commitment, standard definitions of job satisfaction, perceptions of the supervisor, participative decision making, intrinsic motivation, work commitment and job characteristics such as skill variety and job challenge (Blau, 1985; Brown, 1996; Knoop, 1986). Elloy, Everett and Flynn (1991, p.173) indicated that "job-involved individuals are more likely to be satisfied with, and thus more committed to, their jobs and organisations". Knoop (1986) did however note that job involvement could have a different meaning for 8-to-4 factory workers than for professionals who are required to take work home and have the responsibility of planning and organising details of their jobs. Research has also indicated that job involvement is a higher predictor of job performance for those individuals who are committed to an outside profession than those who are committed to their employing organisation, suggesting that job involvement is especially important for knowledge workers who are 'cosmopolitan' and who have internalised professional values (Keller, 1997).

\section{Organisational Citizenship Behaviour}

Organisational citizenship behaviour is a type of discretionary job performance in which employees go beyond prescribed job requirements (in-role behaviours) that are not explicitly recognised by the formal reward system, and engage in helping behaviours aimed at individuals and the organisation as a whole (Organ, 1988). To describe organisational citizenship behaviour, Organ (1988) identified the following five dimensions:

- Altruism, which refers to helping behaviours aimed at specific individuals;

- Conscientiousness, which refers to helping behaviours aimed at the organisation as a whole;

- Sportsmanship, which refers to the willingness on the part of the employee to tolerate less than ideal circumstances without complaining;

- Courtesy, which refers to actions aimed at the prevention of future problems; and

- Civic virtue, which refers to a behaviour of concern for the life of the organisation.

A number of studies have investigated the various indicators of worker citizenship. Research shows that employee behaviour (organisational citizenship behaviour) is positively related to affective commitment (as opposed to continuous commitment), employee involvement in work organisational issues, perceived organisational support, high quality of leadermember exchange, overall evaluations of performance effectiveness, quantity of output, turnover and satisfaction (Allen \& Rush, 1998; Cappelli \& Rogovsky, 1998; Chen, Hui and
Sego, 1998; Deluga, 1998; Organ \& Ryan, 1995; Posdakoff, Ahearne \& MacKenzie, 1997; Posdakoff \& MacKenzie, 1994; Shore, Barksdale and Shore, 1995; Shore \& Wayne, 1993). Van Yperen and Van den Berg (1999) found that when employees feel that they are able to participate in decisions made, they tend to feel supported by their supervisors and consequently exhibit more organisational citizenship behaviours. One can therefore expect employee acts of organisational citizenship behaviour to serve as a behavioural cue on which management bases its presumptions of employee commitment to the organisation (Shore, Barksdale \& Shore, 1995).

In a study examining the relationship between leader behaviour and organisational citizenship behaviour, Schnake and Dumler (1993) found traditional leadership (characterised by the limitation of employee discretion) to contribute more to the prediction of organisational citizenship behaviour than super leadership (characterised by employee autonomy and control). Although these results were unexpected, Schnake and Dumler (1993) believed that a possible reason for these results could be that the jobs in the study were all relatively low task scopes, and that future research should investigate leadership as a predictor of organisational citizenship behaviour with a sample of jobs higher in task scope.

In an attempt to further understand the organisational citizenship behaviour variable, Hodson (1999) hypothesised that just as an employee is expected to perform beyond ordinary expectations, management should also engage in such behaviours. The results of the study indicate that management citizenship behaviours (behaviours that meet a minimum set of workplace norms) are a crucial determinant of worker citizenship behaviour (Hodson, 1999, p. 467), and that management citizenship behaviours are positively associated with bilateral systems (work involving at least some input by workers into decisions about the organisation) and job autonomy.

Following the findings in the literature, it is proposed that employee attitudes and behaviour are affected by leadership style. The study aims to show that (a) transformational and transactional leadership are positively correlated with the constructs of organisational commitment, job satisfaction, job involvement and organisational citizenship behaviour; (b) there are higher significant correlations between transformational leadership and affective commitment, normative commitment, job satisfaction, job involvement and organisational citizenship behaviour than between transactional leadership and these constructs, and (c) there is a statistically significant correlation between transactional leadership and continuance commitment.

\section{METHOD}

\section{Sample}

The participants in this study were executives and senior managers of a major company listed on the Johannesburg Stock Exchange involved in the development and implementation of infrastructure and industry projects and the design and manufacture of engineered products. Two samples were drawn from 18 operating companies, namely all individuals who held management or leadership positions and all subordinates reporting directly to these leaders (referred to hereafter as 'raters').

Due to the size of the company, operating divisions were categorised into four groups, Building and Civil Engineering; Industry and Mining; Engineered Products and Corporate as well as Supplies and Services. Although questionnaires were sent to 62 leaders and 342 raters, only 52 leaders and 276 raters were included in the study. This was primarily due to the fact that the research design required a minimum of three raters per leader. Failure to complete questionnaires by either the leader or the leader's raters meant that they could not be included in the study. 
Of the rater respondents, 91,3\% were male and 8,3\% female. The levels of education of the raters were as follows: $10,5 \%$ had a matric or equivalent, $41,5 \%$ were in possession of a college or technikon qualification, $43,3 \%$ had a university qualification and $4,7 \%$ did not respond. About $37 \%$ of the raters were between the ages of 40 and 49. Of the leader respondents, 94,3\% were male and 5,7\% female. With regard to the representation of leaders in the different company groups, 22,6\% were from Building and Civil Engineering, $22,6 \%$ from Industry and Mining, 15,1\% from Engineered Products and Corporate and 39,6\% from Supplies and Services.

\section{Measuring Instruments}

Transformational, Transactional and Laissez faire Leadership Transformational, transactional and laissez faire leadership styles were measured with the Multifactor Leadership Questionnaire (MLQ)(5X)(Revised), developed by Bass and Avolio (1997)*. Using the MLQ (5X)(Revised), Ackermann, Schepers, Lessing and Dannhauser (2000) reported internal consistency reliability estimates for transformational, transactional and laissez faire leadership of 0,94, 0,80 and 0,74 respectively. The MLQ assesses five components of transformational leadership (Idealised Influence attributes, Idealised Influence- behaviour, Inspirational Motivation, Intellectual Stimulation and Individualised Consideration), three components of transactional leadership (Constructive Transaction, Management by Exception- active and Management by ExceptionPassive), and one non-transactional/laissez faire leadership component. The relevant components were combined to obtain total scores on transformational, transactional and laissez faire leadership. In addition, the MLQ (5X)(Revised) assesses three outcome components (Extra Effort, Effectiveness and Satisfaction). The MLQ items are evaluated on a five-point scale ranging from 0 ("not at all") to 4 ("frequently, if not always"). Two questionnaire forms were completed, namely the self-rating form, where managers rated themselves as leaders, and the rater form, where subordinates of these leaders rated their superiors.

\section{Organisational commitment}

Organisational commitment was measured using the threedimensional Meyer, Allen and Smith (1993) instrument, that was originally developed by Allen and Meyer (1990). The affective, continuance and normative organisational-commitment scales each comprises six items, a modification of the original questionnaire. Meyer, Allen and Smith (1993) reported internal consistency reliability estimates (Cronbach's alpha) for affective commitment (AC), continuance commitment (CC) and normative commitment (NC) as follows: AC, 0,82; CC, 0,74 and NC, 0,83. Responses were made on a 7 point scale $(1=$ strongly disagree and $7=$ strongly agree $)$ and were averaged to yield composite commitment scores for each leader.

\section{Job involvement}

Kanungo's (1982a, p. 169-170) 10-item Job Involvement Scale was used, without filter items to measure the degree to which each rater identified with his or her present job. Kanungo (1982b) reported internal consistency and test-retest reliability coefficients of 0,87 and 0,85 respectively. The items were responded to on a six-point scale $(1=$ Agree strongly and $6=$ Disagree strongly), and were averaged to yield a composite Job Involvement score for each leader.

\section{Job satisfaction}

Job satisfaction was assessed using the 18-item Job in General Scale, which was used to measure overall feelings about the job. The scale required respondents to combine their reactions to various aspects of the job into a single integrated response by responding with a yes to a positive item and no to a negative item. A total score, based on the 18 items, was calculated and averaged across the raters for each leader. For interpretation purposes an average score of 18 signifies a very high level of job satisfaction and a 0 a very low level of job satisfaction. Ironson, Smith, Brannick, Gibson and Paul (1989), reported an internal consistency coefficient for the scale (coefficient alpha) of 0,91.

The MLQ (5X) (Revised) (Copyright 1995 by Bernard M. Bass and Bruce J. Avolio), was used with permission of Productivity Development (Pty) Ltd, P.O. Box 756, Randburg, 2125.

\section{Organisational citizenship behaviour}

Three aspects of citizenship behaviour were measured - helping behaviour, sportsmanship and civic virtue, using Posdakoff, Ahearne and MacKenzie's (1997) instrument. Posdakoff, Ahearne and MacKenzie reported internal consistency reliability estimates (Cronbach's alpha) for Helping, 0,95; Civic Virtue, 0,96 and Sportsmanship, 0,88. Organisational citizenship behaviour measures were obtained on a 7-point scale ranging from $1=$ strongly disagree to $7=$ strongly agree .

Work Behaviours

In order to obtain additional information regarding each of the rater's work behaviours, it was decided to include a four-item scale focusing on general work behaviours. Example items are: "on average, how many hours overtime do you work per week?" and "How many times a week do you take lunch?"

\section{Procedure}

The chief executive of the company introduced the study to all executives and senior managers and personally encouraged them to participate in the study so as to gain important insight into the leadership styles and environment of the Group. Due to the nature of the study, it was necessary to use a two-fold approach. All directors/executives were first asked to complete the MLQ as a self-rating, indicating how frequently, or to what degree, they believed they engaged in the specific behaviours identified. Thereafter all raters were requested to completed a survey pack which contained personal profile information as well as the MLQ (Rater), Organisational Commitment Questionnaire, Work Behaviour Assessment Form, Job Satisfaction Questionnaire, Job Involvement Questionnaire and the Organisational Citizenship Behaviour Questionnaire. All questionnaires were personalised with the name of the executive/senior manager and the company name. The author also ensured that each rater's questionnaire included his/her immediate superior's name for control purposes.

A private e-mail facility was set up with a password, accessible only by the first author. Questionnaires were e-mailed to all leaders and those subordinates reporting directly to these leaders. Each questionnaire had a covering letter inviting subjects to participate in the study and assuring them that their individual responses would remain confidential. Questionnaires were distributed using the e-mail facility because of the geographical dispersion of the various operating companies and the fact that many of the participants' work schedules did not allow for personal administration of the questionnaires. Participants were requested to complete the questionnaires and return them to the author either via e-mail or in a sealed envelope to a central location. Because control of the study was of utmost importance, the author created a checklist per company and tabled the names of each rater per leader. Completed questionnaires were recorded against this checklist.

\section{RESULTS}

The descriptive statistics and reliabilities of the various measures are shown in Table 1 . It should be noted that the results of the work behaviour items were omitted due to an exceptionally poor response rate on these items. It should further be noted that because the number of raters per leader varied considerably, although the difference in their ratings was minimal, a mean score was computed across all raters for each respective leader. Two sets of descriptive statistics for the rater MLQ results are provided in Table 1, namely the results for the 276 raters and also the results based on the mean rater scores per leader. The mean rater scores were used for testing the hypotheses. 
TABLE 1

Descriptive Statistics ANd Reliabilities for THE VARIOUS MEASURING INSTRUMENTS FOR RATERS $(\mathbf{N}=\mathbf{2 7 6})$ AND LEADERS $(\mathbf{N}=\mathbf{5 2})$

\begin{tabular}{|c|c|c|c|c|}
\hline Variable & $\mathrm{N}$ & M & SD & $\begin{array}{c}\text { Cronbach } \\
\text { alpha }\end{array}$ \\
\hline \multicolumn{5}{|l|}{ MLQ (Raters) } \\
\hline Idealised Influence (attributes) & 276 & 2,98 & 0,81 & 0,81 \\
\hline Idealised Influence (behaviour) & 276 & 2,86 & 0,75 & 0,77 \\
\hline Inspirational Motivation & 276 & 3,02 & 0,82 & 0,86 \\
\hline Intellectual Stimulation & 276 & 2,74 & 0,79 & 0,78 \\
\hline Individualised Consideration & 276 & 2,38 & 0,85 & 0,73 \\
\hline Constructive Consideration & 276 & 2,70 & 0,87 & 0,77 \\
\hline Management by Exception (active) & 276 & 2,38 & 0,86 & 0,75 \\
\hline Management by Exception (passive) & 276 & 1,22 & 0,74 & 0,54 \\
\hline Laissez Faire & 276 & 0,95 & 0,85 & 0,72 \\
\hline Extra Effort & 276 & 2,74 & 0,92 & 0,84 \\
\hline Effectiveness & 276 & 2,82 & 0,80 & 0,74 \\
\hline Satisfaction & 276 & 3,00 & 0,84 & 0,84 \\
\hline \multicolumn{5}{|l|}{ MLQ (Raters - mean scores) } \\
\hline Idealised Influence (attributes) & 52 & 2,89 & 0,58 & \\
\hline Idealised Influence (behaviour) & 52 & 2,80 & 0,54 & \\
\hline Inspirational Motivation & 52 & 2,93 & 0,62 & \\
\hline Intellectual Stimulation & 52 & 2,70 & 0,47 & \\
\hline Individualised Consideration & 52 & 2,33 & 0,57 & \\
\hline Constructive Consideration & 52 & 2,64 & 0,60 & \\
\hline Management by Exception (active) & 52 & 2,35 & 0,52 & \\
\hline Management by Exception (passive) & 52 & 1,23 & 0,40 & \\
\hline Laissez Faire & 52 & 1,00 & 0,59 & \\
\hline Extra Effort & 52 & 2,65 & 0,60 & \\
\hline Effectiveness & 52 & 2,76 & 0,53 & \\
\hline Satisfaction & 52 & 2,94 & 0,58 & \\
\hline \multicolumn{5}{|l|}{ MLQ (Leaders) } \\
\hline Idealised Influence (attributes) & 52 & 3,13 & 0,49 & 0,59 \\
\hline Idealised Influence (behaviour) & 52 & 3,19 & 0,47 & 0,59 \\
\hline Inspirational Motivation & 52 & 3,20 & 0,52 & 0,73 \\
\hline Intellectual Stimulation & 52 & 3,21 & 0,45 & 0,67 \\
\hline Individualised Consideration & 52 & 3,21 & 0,46 & 0,54 \\
\hline Constructive Consideration & 52 & 3,12 & 0,52 & 0,46 \\
\hline Management by Exception (active) & 52 & 2,46 & 0,77 & 0,76 \\
\hline Management by Exception (passive) & 52 & 0,92 & 0,50 & 0,44 \\
\hline Laissez Faire & 52 & 0,39 & 0,47 & 0,52 \\
\hline Extra Effort & 52 & 3,19 & 0,51 & 0,80 \\
\hline Effectiveness & 52 & 3,18 & 0,44 & 0,52 \\
\hline Satisfaction & 52 & 3,21 & 0,46 & 0,38 \\
\hline \multicolumn{5}{|l|}{ Leadership Styles (Raters) } \\
\hline Transformational Leadership & 276 & 2,76 & 0,67 & 0,92 \\
\hline Transactional Leadership & 276 & 2,09 & 0,46 & 0,54 \\
\hline Laissez Faire Leadership & 276 & 0,95 & 0,85 & 0,72 \\
\hline \multicolumn{5}{|l|}{ Organisational Commitment } \\
\hline Affective Commitment & 272 & 5,50 & 1,07 & 0,77 \\
\hline Continuance Commitment & 272 & 3,50 & 1,31 & 0,79 \\
\hline Normative Commitment & 272 & 4,64 & 1,28 & 0,82 \\
\hline Job Involvement & 271 & 4,18 & 0,81 & 0,83 \\
\hline Job Satisfaction & 272 & 14,94 & 2,53 & 0,82 \\
\hline \multicolumn{5}{|c|}{ Organisational Citizenship Behaviour } \\
\hline Helping Behaviour & 272 & 5,85 & 0,62 & 0,74 \\
\hline Civic Virtue & 271 & 5,83 & 0,80 & 0,64 \\
\hline Sportsmanship & 271 & 5,62 & 1,01 & 0,47 \\
\hline
\end{tabular}

The affective, normative and continuance commitment mean scores were 5,50, 4,64 and 3,50 respectively. The mean scores for job involvement, job satisfaction and organisational citizenship behaviour were above their respective scale midpoints.

The internal consistency coefficients for the MLQ (raters), organisational commitment, job involvement and job satisfaction measures were generally acceptable $(>0,70)$ except for the MLQ dimension of Management by Exception, passive $(0,54)$. The internal consistency coefficients for the MLQ (leaders) were not acceptable for several scales, probably as a result of the small sample size. The intercorrelations between the rater mean scores on the MLQ scales were calculated and are reported in Table 2 . The only scale that did not correlate strongly with all the other scales, was Management by Exception (active). It was therefore decided to obtain a composite score for the three leadership styles separately and to use these in the analyses to follow. The reliabilities of the three leadership styles based on the rater mean scores were also computed, namely 0,92 for transformational leadership, 0,54 for transactional leadership and 0,72 for laissez faire leadership (see Table 1).

The internal consistency coefficients for the organisational citizenship behaviour dimensions of Civic Virtue $(\mathrm{r}=0,64)$ and Sportsmanship $(0,47)$ were also found to be non-acceptable. In order to assess whether the organisational citizenship behaviour measure was reliable overall, the reliability of the total scale was computed, which yielded a coefficient of 0,62 . On the grounds of these unsatisfactory reliability results, it as decided to carry out an exploratory factor analysis on the organisational citizenship behaviour measure to determine whether the questionnaire would yield dimensions with acceptable psychometric properties.

The Kaiser-Meyer-Olkin measure of sampling adequacy (MSA) was equal to 0,78 and the Bartlett test for sphericity was $613,45(p<0,000)$ indicating that the sample used was adequate and that there was sufficient justification to perform a factor analysis. The 13 items of the organisational citizenship behaviour questionnaire were subjected to a principal axis factor analysis using a varimax rotation, which resulted in four factors being extracted. Subscores were determined for each of these factors, which were then intercorrelated and subjected to a second order factor analysis. The obtained factor matrix was obliquely rotated to a simple structure using the direct oblimin procedure. Two factors were obtained, namely Helping Behaviour and Civic Virtue, as shown in Table 3. Due to the high correlation between these two factors, they were combined to yield a single organisational citizenship behaviour dimension with a reliability coefficient of 0,76 .

In order to establish whether there were any significant differences between the rater mean scores and the leaders' self-ratings on each of the three leadership styles, t-tests were performed. Table 4 indicates significant differences in the ratings of transformational $(\mathrm{p}<0,000)$ and laissez faire leadership $(p<0,000)$. No significant difference was however found for transactional leadership $(p=0,062)$. When the leadership styles according to the perceptions of the raters and the leaders were compared, $99,1 \%$ of the leaders rated themselves as transformational, whereas the raters indicated that only 90,6\% were transformational and 7,5\% laissez faire. Interestingly, neither the leaders nor the raters indicated transactional leadership as a dominant leadership style. Leadership styles according to the leaders and raters are shown in Table 5 . These results support findings in previous research that self-report ratings are more favourable than ratings by others. 
TABLE 2

INTERCORRELATIONS BETWEEN THE MLQ SCALES (RATER MEANS, N=52)

\begin{tabular}{|c|c|c|c|c|c|c|c|c|c|}
\hline MLQ scale & $\begin{array}{l}\text { Idealised } \\
\text { influence- } \\
\text { attributes }\end{array}$ & $\begin{array}{l}\text { Idealised } \\
\text { influence- } \\
\text { behaviour }\end{array}$ & $\begin{array}{l}\text { Inspirational } \\
\text { motivation }\end{array}$ & $\begin{array}{l}\text { Intellectual } \\
\text { stimulation }\end{array}$ & $\begin{array}{l}\text { Individualised } \\
\text { consideration }\end{array}$ & $\begin{array}{l}\text { Constructive } \\
\text { consideration }\end{array}$ & $\begin{array}{l}\text { Management by } \\
\text { exception-active }\end{array}$ & $\begin{array}{l}\text { Management by } \\
\text { exception- passive }\end{array}$ & Laissez faire \\
\hline $\begin{array}{l}\text { Idealised influence- } \\
\text { attributes }\end{array}$ & 1,00 & & & & & & & & \\
\hline $\begin{array}{l}\text { Idealised influence- } \\
\text { behaviour }\end{array}$ & 0,79 ** & 1,00 & & & & & & & \\
\hline $\begin{array}{l}\text { Inspirational } \\
\text { motivation }\end{array}$ & $0,86^{* *}$ & 0,78 ** & 1,00 & & & & & & \\
\hline $\begin{array}{l}\text { Intellectual } \\
\text { stimulation }\end{array}$ & 0,77 * * & 0,67 * * & 0,74 * * & 1,00 & & & & & \\
\hline $\begin{array}{l}\text { Individualised } \\
\text { consideration }\end{array}$ & 0,79 * * & $0,65^{* *}$ & 0,70 ** & 0,79 * * & 1,00 & & & & \\
\hline $\begin{array}{l}\text { Constructive } \\
\text { consideration }\end{array}$ & $0,87^{* *}$ & 0,74 * * & $0,83^{* *}$ & 0,74 ** & $0,85^{* *}$ & 1,00 & & & \\
\hline $\begin{array}{l}\text { Management by } \\
\text { exception-active }\end{array}$ & 0,30 * & 0,31 * & 0,16 & 0,31 * & $-0,37$ ** & 0,43 * * & 1,00 & & \\
\hline $\begin{array}{l}\text { Management by } \\
\text { exception- passive }\end{array}$ & $-0,72$ ** & $-0,64$ ** & $-0,65$ * * & $-0,67$ ** & $-0,63$ ** & $-0,63$ ** & $-0,35^{*}$ & 1,00 & \\
\hline Laissez faire & $-0,67$ * * & $-0,59$ * * & $-0,58$ ** & $-0,48 * *$ & $-0,59 * *$ & $-0,66^{* *}$ & $-0,23$ & 0,68 ** & 1,00 \\
\hline
\end{tabular}

TABLE 3

ROTATED FACTOR MATRIX OF THE ORGANISATIONAI CITIZENSHIP BEHAVIOUR QUESTIONNAIRE

\begin{tabular}{lcc}
\hline Items & Helping Behaviour & Civic Virtue \\
\hline OCB2 & 0,57 & 0,27 \\
OCB4 & 0,58 & \\
OCB5 & 0,57 & 0,19 \\
OCB1 & 0,57 & \\
OCB7 & 0,51 & 0,32 \\
OCB3 & 0,48 & \\
OCB6 & 0,40 & 0,24 \\
OCB9 & & 0,70 \\
OCB8 & 0,35 & $\mathbf{0 , 5 4}$ \\
OCB10 & 0,14 & $\mathbf{0 , 6 1}$ \\
\hline
\end{tabular}

TABLE 4

TEST FOR DIFFERENCES BETWEEN LEADER AND RATER RESPONSES to The MLQ (Transformational, Transactional and LAISSEZ FAIRE LEADERSHIP)

\begin{tabular}{lcccccc}
\hline & \multicolumn{5}{c}{ Paired Differences } \\
\cline { 2 - 7 } Variable & $\begin{array}{c}\text { Mean } \\
\text { difference }\end{array}$ & SD & SE & t & df & p (2-tailed) \\
\hline $\begin{array}{l}\text { Transformational } \\
\text { leadership }\end{array}$ & 0,44 & 0,48 & 0,07 & 6,55 & 51 & 0,000 \\
$\begin{array}{l}\text { Transactional } \\
\text { leadership }\end{array}$ & 0,09 & 0,35 & 0,05 & 1,91 & 51 & 0,062 \\
$\begin{array}{l}\text { Laissez Faire } \\
\text { leadership }\end{array}$ & $-0,61$ & 0,67 & 0,09 & $-6,54$ & 51 & 0,000 \\
\hline
\end{tabular}

An objective of the study was to assess the interrelationships between transformational, transactional and laissez faire leadership and organisational commitment, job satisfaction, job involvement and organisational citizenship behaviour. The interrelationships between the variables were computed using Pearson's product moment correlation to identify the direction and strength of the relationships between each of the variables. Subsequently, canonical correlation analyses were performed to assess the overall correlation between the independent and dependent variables.
TABLE 5

Perceived LeAdership STYle according to LEADERS AND RATERS $(\mathrm{N}=\mathbf{5 2})$

\begin{tabular}{lcc}
\hline & Frequency & Percent \\
\hline$\underline{\text { Leader }}$ & 52 & 99,1 \\
Transformational & & \\
$\underline{\text { Rater }}$ & 48 & 90,6 \\
Transformational & 4 & 7,5 \\
Laissez Faire & & \\
\hline
\end{tabular}

Table 6 presents the results of the intercorrelation matrix. Significant correlations were obtained between the leadership dimensions. Both transformational and transactional leadership correlated positively with affective commitment $(\mathrm{r}=0,45$ and $0,46)$. No significant correlation was found between continuance commitment and transformational and transactional leadership. Furthermore, no significant correlation was found between transactional leadership and normative commitment. A significant correlation was found between transformational leadership and normative commitment $(\mathrm{r}=$ $0,34)$ and organisational citizenship behaviour $(r=0,28)$. A surprising result, however, was that transformational and transactional leadership did not correlate significantly with the constructs of job involvement and job satisfaction. The results indicate that laissez faire leadership does not correlate with the variables of affective commitment, continuance commitment, normative commitment, job involvement, job satisfaction and organisational citizenship behaviour. In line with the high affective and normative mean scores obtained, the intercorrelation matrix indicates a significant correlation between these two variables $(r=0,55)$. The results further indicate significant correlations between normative commitment and job involvement $(\mathrm{r}=0,36)$, job satisfaction $(\mathrm{r}=$ $0,53)$ and organisational citizenship behaviour $(r=0,53)$. Furthermore, and in line with previous research findings, significant correlations were found between (a) affective commitment and job involvement $(r=0,37)$, job satisfaction $(r=$ $0,56)$ and organisational citizenship behaviour $(r=0,52)$, (b) job involvement with job satisfaction $(r=0,46)$ and organisational citizenship behaviour $(0,40)$ and (c) job satisfaction and organisational citizenship behaviour $(r=0,37)$. 
TABLE 6

INTERCORRELATION MATRIX OF RATERS' SCORES $(\mathbf{N}=\mathbf{5 2})$

\begin{tabular}{|c|c|c|c|c|c|c|c|c|c|}
\hline & $\mathrm{TF}$ & TA & LF & $\mathrm{AC}$ & CC & $\mathrm{NC}$ & JI & JS & OCB \\
\hline TF & 1,00 & & & & & & & & \\
\hline TA & $\begin{array}{c}0,56 \\
(0,000)\end{array}$ & & 1,00 & & & & & & \\
\hline LF & $\begin{array}{c}-0,66 \\
(0,000)\end{array}$ & $\begin{array}{c}-0,32 \\
(0,020)\end{array}$ & 1,00 & & & & & & \\
\hline $\mathrm{AC}$ & $\begin{array}{c}0,45 \\
(0,001)\end{array}$ & $\begin{array}{c}0,46 \\
(0,001)\end{array}$ & $\begin{array}{c}-0,24 \\
(0,066)\end{array}$ & 1,00 & & & & & \\
\hline CC & $\begin{array}{c}-0,15 \\
(0,279)\end{array}$ & $\begin{array}{c}0,02 \\
(0,872)\end{array}$ & $\begin{array}{c}0,11 \\
(0,450)\end{array}$ & $\begin{array}{c}-0,12 \\
(0,409)\end{array}$ & 1,00 & & & & \\
\hline $\mathrm{NC}$ & $\begin{array}{c}0,34 \\
(0,019)\end{array}$ & $\begin{array}{c}0,26 \\
(0,061)\end{array}$ & $\begin{array}{c}-0,11 \\
(0,446)\end{array}$ & $\begin{array}{c}0,55 \\
(0,000)\end{array}$ & $\begin{array}{c}0,14 \\
(0,327)\end{array}$ & 1,00 & & & \\
\hline JI & $\begin{array}{c}0,11 \\
(0,448)\end{array}$ & $\begin{array}{c}0,13 \\
(0,354)\end{array}$ & $\begin{array}{c}0,20 \\
(0,149)\end{array}$ & $\begin{array}{c}0,37 \\
(0,006)\end{array}$ & $\begin{array}{c}0,08 \\
(0,567)\end{array}$ & $\begin{array}{c}0,36 \\
(0,009)\end{array}$ & 1,00 & & \\
\hline JS & $\begin{array}{c}0,24 \\
(0,081)\end{array}$ & $\begin{array}{c}0,11 \\
(0,434)\end{array}$ & $\begin{array}{c}-0,14 \\
(0,323)\end{array}$ & $\begin{array}{c}0,56 \\
(0,000)\end{array}$ & $\begin{array}{c}-0,05 \\
(0,703)\end{array}$ & $\begin{array}{c}0,53 \\
(0,000)\end{array}$ & $\begin{array}{c}0,46 \\
(0,001)\end{array}$ & 1,00 & \\
\hline ОСВ & $\begin{array}{c}0,28 \\
(0,045)\end{array}$ & $\begin{array}{c}0,02 \\
(0,907)\end{array}$ & $\begin{array}{c}-0,18 \\
(0,204)\end{array}$ & $\begin{array}{c}0,52 \\
(0,000)\end{array}$ & $\begin{array}{c}0,01 \\
(0,968)\end{array}$ & $\begin{array}{c}0,54 \\
(0,000)\end{array}$ & $\begin{array}{c}0,40 \\
(0,003)\end{array}$ & $\begin{array}{c}0,37 \\
(0,007)\end{array}$ & 1,00 \\
\hline
\end{tabular}

Note: Values between brackets indicate the exact $\mathrm{p}$ values

$\mathrm{TF}=$ Transformational Leadership; $\mathrm{TA}=$ Transactional Leadership; $\mathrm{LF}=$ Laissez Faire Leadership; $\mathrm{AC}=$ Affective Commitment; CC= Continuance Commitment; NC= Normative Commitment; JI= Job Involvement; JS= Job Satisfaction; $\mathrm{OCB}=$ Organisational Citizenship Behaviour

Two canonical correlation analyses were performed. Firstly, an analysis was performed using the leadership styles (raters) as independent variables and the attitude and behaviour variables as dependent variables.

In order to determine the number of statistically significant canonical correlations, Bartlett's chi-square test was performed. Table 7 shows the results of Bartlett's chi-square test based on the mean scores of the raters on all variables. It appeared that at least the first eigenvalue was significant and the researcher was thus entitled to interpret the first set of canonical correlations given in Table 8 .

TABLE 7

Statistical Significance of Canonical Correlations BARTLETT'S TEST (RATERS)

\begin{tabular}{lccccc}
\hline Eigenvalue & $\begin{array}{c}\text { Canonical } \\
\text { correlation }\end{array}$ & $\begin{array}{c}\text { No of eigen- } \\
\text { values removed }\end{array}$ & Chi-square & df & $\mathbf{p}$ \\
\hline 0,372 & 0,61 & 0 & 38,69 & 18 & 0,003 \\
0,199 & 0,45 & 1 & 16,80 & 10 & 0,079 \\
0,127 & 0,36 & 2 & 6,36 & 4 & 0,174 \\
\hline
\end{tabular}

TABLE 8

CANONICAL CORRELATION ANALYSIS OF THE LEADERSHIP STYLES

(RATERS) AS INDEPENDENT VARIABLES AND THE ATTITUDES AND BEHAVIOUR VARIABLES AS DEPENDENT VARIABLES

\begin{tabular}{lc}
\hline & $\begin{array}{c}\text { Correlations of original measures } \\
\text { with canonical variate }\end{array}$ \\
\hline Independent Variables & 0,53 \\
Transformational Leadership & 0,92 \\
Transactional Leadership & $-0,004$ \\
Laissez Faire Leadership & $37,42 \%$ \\
Percentage of variance explained & $13,93 \%$ \\
Redundancy index & \\
Dependent Variables & 0,74 \\
Affective Commitment & 0,03 \\
Continuance Commitment & 0,49 \\
Normative Commitment & 0,43 \\
Job Involvement & 0,19 \\
Job Satisfaction & 0,05 \\
Organisational citizenship behaviour & $16,88 \%$ \\
Percentage of variance explained & $6,28 \%$ \\
Redundancy index &
\end{tabular}

In order to interpret the 'meaning' of each canonical variate pair, the factor structure method was used. Those variables that correlate highly with a canonical variate can be regarded as having more in common with it. The correlations of the original measures with the first canonical variate pair are given in Table 8. It is apparent that transactional leadership $(0,92)$ is significantly correlated with the independent canonical variate, whilst affective commitment $(0,74)$ is significantly correlated with the dependent canonical variate. Furthermore, the results indicate that transformational leadership $(0,53)$ is positively correlated with the independent variate and normative commitment $(0,49)$ and job involvement $(0,43)$ are positively correlated with the dependent variate. The canonical correlation between the independent and the dependent variates is 0,61 . Thus $37,23 \%$ (Table 7 ) of the variance of the dependent variate is accounted for by the independent variate. It can also be seen from Table 8 that the independent canonical variate accounts for $37,42 \%$ of the variance of the original independent variables and the dependent canonical variate accounts for $16,88 \%$ of the variance of the original dependent variables. If one considers the redundancy index, it appears that the independent canonical variate accounts for $13,93 \%$ of the dependent variables and the dependent canonical variate accounts for $6,28 \%$ of the variance of the independent variables.

For the second canonical correlation analysis, leadership styles (leaders) were used as independent variables and the attitudes and behaviour variables were used as dependent variables. Table 9 shows the results of Bartlett's chi-square test based on the leaders' MLQ results and the raters mean scores for the affective commitment, continuance commitment, normative commitment, job involvement, job satisfaction and organisational citizenship behaviour variables. It appeared that the first eigenvalue is not significant and therefore an interpretation of the first canonical correlation is not indicated.

TABLE 9

Statistical Significance of Canonical Correlations BARTLETT'S TEST FOR LEADER RATINGS

\begin{tabular}{lccccc}
\hline Eigenvalue & $\begin{array}{c}\text { Canonical } \\
\text { correlation }\end{array}$ & $\begin{array}{c}\text { No of eigen- } \\
\text { values removed }\end{array}$ & Chi-square & df & p \\
\hline 0,166 & 0,41 & 0 & 12,43 & 18 & 0,824 \\
0,076 & 0,28 & 1 & 3,88 & 10 & 0,921 \\
0,004 & 0,06 & 2 & 0,17 & 4 & 0,996 \\
\hline
\end{tabular}




\section{DISCUSSION}

The primary objective of this study was to examine the relationship between leadership style and employee attitudes and behaviour, and whether the strength of the relationship was greater for transformational than transactional leaders. Leadership theory suggests a stronger, positive relationship between transformational leadership and organisational commitment, job satisfaction, job involvement and organisational citizenship behaviour, however previous researchers (Judge \& Bono, 2000; Schnake \& Dumler, 1993) have called for more research to support such a link. This study responds to this call and thus fills an important void in the leadership literature.

Both the intercorrelations and canonical correlation analyses of the rater mean scores revealed that the most prominent significant relationship is between transactional leadership and affective commitment. Interestingly, the results of the canonical correlations based on the leaders ratings, indicated that no significant canonical correlation was found.

From the intercorrelation matrix for raters (Table 6), it was found that there was a significant and positive correlation between transactional leadership and affective commitment $(\mathrm{r}=0,46)$. However the correlation between transformational leadership and affective commitment was also positive and significant ( $\mathrm{r}=$ 0,45). At the same time, Table 8 indicates that, although transactional leadership best describes the independent canonical variate $(r=0,92)$, transformational leadership is also positively correlated with the independent variate $(r=0,53)$. Given the significant correlation between transformational and transactional leadership $(r=0,56)$, one could expect to obtain a significant and positive correlation of both transformational and transactional leadership with affective commitment. These findings support the author's prediction of a positive relationship between affective commitment and transformational and transactional leadership. However, it does not support the hypothesis of a higher correlation between transformational leadership and affective commitment than between transactional leadership and affective commitment. In retrospect, several factors may explain these results.

First, the results seem understandable given that transactional leadership is based on an exchange of information between leaders and followers for various kinds of rewards. When this transactional relationship is acceptable to the follower, there may be a feeling of emotional attachment towards the organisation. This could also possibly explain the nonsignificant correlation between transactional leadership and continuance commitment. Secondly, effective leaders typically display both transformational and transactional characteristics, as evidenced by the positive correlations between these two styles of leadership. This supports previous findings in the literature (Avolio \& Bass, 1999; Bass \& Steidlmeier, 1998; Hartog \& Van Muijen, 1997), and suggests that effective executives use a combination of distinct leadership styles, each in the right measure and at the right time. Although results indicate a strong correlation between transformational and transactional leadership, it is interesting to note that both leaders and raters perceive transformational leadership to be the dominant leadership style (Table 5).

The significant differences in the ratings between the rater mean scores and leaders mean ratings on transformational leadership (Table 4), support theories that self-ratings are consistently higher than rater responses. Respondents tend to give socially desirable responses as opposed to actual behaviours in action. Thirdly, the low internal consistency $(0,54)$ of the transactional leadership scale may be the cause for the non-significant relationships with other variables. Finally, the average age of the respondents may be a factor in this study. The majority of respondents in the sample were above the age of 40 , indicating that they possibly have well established leadership patterns and could therefore find it difficult and uncomfortable to change to a more transforming leadership style.

The high correlation between affective commitment and normative commitment is noteworthy. By means of a brief historical overview, many of the participants in this study had been with the company for a long time and have therefore been involved in the structural changes that have taken place. In addition, this company employed a number of new executives/senior managers before and during these changing times. Based on the history of the company, the results do not seem surprising at all. The high levels of normative commitment could be a result of those executives/senior managers who have been with the company for a long time and therefore feel duty-bound to remain with the company during its difficult times or they are new employees who remain with the organisation because they feel that they ought to. The high levels of affective commitment describe those longstanding loyal executives/senior managers who are emotionally attached to the organisation and its purpose.

A surprising result of this study is that transformational and transactional leadership did not correlate significantly with job involvement and job satisfaction. Although Judge and Bono (2000) found no relationship between transformational leadership and overall job satisfaction, a finding of no significant correlation between transformational leadership and job involvement is not supported by previous research found in the literature (Knoop, 1986). The mean job involvement $(4,18)$ and job satisfaction $(14,94)$ scores as shown in Table 1, provide evidence of above average levels of job involvement and job satisfaction in this company. However, the results indicate that transformational and transactional leadership do not affect these constructs. A possible explanation for such a result is the status and gender of the sample that was drawn. Individuals included in this sample were predominantly male professionals with expert knowledge in their respective fields. Perhaps the content and quality of their work, personal status, reward strategy and working environment contribute more to their level of job involvement and job satisfaction than leadership style. In addition, one wonders whether these results would have been different if there was an equal number of males and females.

The significant correlation between transformational leadership and organisational citizenship behaviour was expected. As suggested in the literature, organisational citizenship is a behavioural activity in which employees go beyond prescribed job requirements, an activity that is presumed to be the effect of a transformational leader. Although Schnake and Dumler (1993) found transactional leadership to contribute more to the prediction of organisational citizenship behaviour than did super leadership (characterised by employee autonomy and control), this result was unexpected and thought to be the result of the jobs in the study all being relatively low task scopes. This study responded to their call to investigate leadership as a predictor of organisational citizenship behaviour with a sample of jobs higher in task scope, and consequently supports their initial expectation of a significant relationship between transformational leadership and organisational citizenship behaviour.

A number of limitations of the study have been identified. First, there was a disproportionate number of transformational, transactional and laissez faire leaders in the sample primarily because the author did not identify these sample groups prior to carrying out the study. Future research should evaluate the relationship between leadership style and employee attitudes and behaviour using pre-determined sample groups. Second, the use of a single organisation as the research site is a potential limitation on the generalisability of these results. Attempts should be made to replicate these analyses in a number of different industries. Third, the results were obtained at a time when the company was experiencing large scale restructuring that could have affected individual perceptions of each of the variables measured. Future 
studies may improve on the current findings by replicating the research in an organisation where structural changes are minimal.

In summary, this study makes a contribution to our knowledge of leadership in that it evaluates the relationship between leadership style and employee levels of organisational commitment, job satisfaction, job involvement and organisational citizenship behaviour. Although transformational and transactional leadership did not correlate significantly with job involvement and job satisfaction, the study provides evidence of a significant relationship between transactional leadership and affective commitment, transformational leadership and affective commitment (to a lesser degree), normative commitment as well as organisational citizenship behaviour. The results further indicate a significant relationship between affective commitment and normative commitment. It is thus hoped that this study will stimulate future research into the relationship between leadership style and employee attitudes and behaviours.

\section{REFERENCES}

Ackermann, C.P., Schepers, J.M., Lessing, B.C. \& Dannhauser, Z. (2000). The factor structure of Bass's Multifactor Leadership Questionnaire in the South African context. Journal of Industrial Psychology, 26 (2), 58-65.

Agho, A.O. \& Price, J.L. (1992). Discriminant validity of measures of job satisfaction, positive affectivity and negative affectivity. Journal of Occupational and Organisational Psychology, 65 (4), 185-197.

Allen, N.J. \& Meyer, J.P. (1990). The measurement and antecedents of affective, continuance and normative commitment to the organisation. Journal of Occupational Psychology, 63 (1), 1-18.

Allen, T.D. \& Rush, M.C. (1998). The effects of organisational citizenship behavior on performance judgments: A field of study and a laboratory experiment. Journal of Applied Psychology, 83 (2), 247-260.

Avolio, B.J. \& Bass, B.M. (1999). Re-examining the components of transformational and transactional leadership using the multifactor leadership questionnaire. Journal of Occupational and Organisational Psychology, 72 (4), 441-463.

Bailey, D.A. (1999). Strategy development processes and participation in decision making: Predictors of role stressors and job satisfaction. Journal of Applied Management Studies, $8,27$.

Barbuto, J.E. (1997). Taking the charisma out of transformational leadership. Journal of Social Behavior and Personality, 12 (3), 689-690.

Bass, M.B. \& Avolio, B.J. (1997). Full range leadership development. Manual for the Multifactor Leadership Questionnaire. California: Mind Garden.

Bass, M.B. \& Steidlmeier, P. (1998). Ethics, character and authentic transformational leadership. Binghamton University, Binghamton, New York.

Available: http://cls.binghamton.edu/BassSteid.html. October 2000)

Bassett, G. (1994). The case against job satisfaction. Business Horizons, 37 (3), 61-68.

Berg, P. (1999). The effects of high performance work practices on job satisfaction in the United States steel industry. Industrial Relations, 54, 111-112.

Blau, G.J. (1985). A multiple study investigation of the dimensionality of job involvement. Journal of Vocational Behavior, 27, 19-36.

Blau, G.J. (1999). Testing the longitudinal impact of work variables and performance appraisal satisfaction on subsequent overall job satisfaction. Human Relations, 52 (8), 1099.

Bleeker, M.M.E. \& Roodt, G. (2002). Die verband tussen werkbetrokkenheid en werkprestasie (The relationship between work involvement and work performance). $S A$ Journal of Industrial Psychology, 28 (1), 22-32.
Boyle, B.A. (1997). A multi-dimensional perspective on salesperson commitment. Journal of Business and Industrial Marketing, 12 (5-6), 354.

Brooke, P.P., Russell, D.W. \& Price, J.L. (1988). Discriminant validation of measures of job satisfaction, job involvement, and organisational commitment. Journal of Applied Psychology, 73 (2), 139-145.

Brown, S.P. (1996). A meta-analysis and review of organisational research on job involvement. Psychological Bulletin, 120 (2), 235-255.

Caldwell, D.F., Chatman, J.A. \& O'Reilly, C.A. (1990). Building organisational commitment: A multiform study. Journal of Occupational Psychology, 63, 245-261.

Cappelli, P. \& Rogovsky, N. (1998). Employee involvement and organisational citizenship: Implications for labor law reform and 'lean production'. Industrial and Labor Relations Review, 51 (4), 633-654.

Carless, S.A. (1998). Assessing the discriminant validity of transformational leader behaviors as measured by the MLQ. Journal of Occupational and Organisational Psychology, 71 (4), 353-358.

Chen, X.; Hui, C. \& Sego, D.J. (1998). The role of organisational citizenship behavior in turnover: Conceptualization and preliminary tests of key hypotheses. Journal of Applied Psychology, 83 (6), 922-931.

Covin, T.J. \& Kolenko, T.A. (1997). Leadership style and postmerger satisfaction. Journal of Management Development, 16 (1), 22-34.

Cropanzano, R., James, K. \& Konovsky, M.A. (1993). Dispositional affectivity as a predictor of work attitudes and job performance. Journal of Organisational Behavior, 14, 595606.

Deluga, R.J. (1998). Leader-member exchange quality and effectiveness ratings. Group and Organisation Management, 23 (2), 189-116.

Eisenberger, R., Fasolo, P. \& Davis-LaMastro (1990). Perceived organizational support and employee diligence, commitment, and innovation. Journal of Applied Psychology, 75 (1), 51-59.

Elloy, D.F., Everett, J.E. \& Flynn, W.R. (1991). An examination of the correlates of job involvement. Group and Organisational Studies, 16 (2), 160-177.

Harkins, P.J. (1998). Why employees stay-or go. Workforce, 77 (10), 74-79.

Hartog, D.N. \& Van Muijen, J. (1997). Transactional versus transformational leadership: An analysis of the MLQ. Journal of Occupational and Organisational Psychology, 70 (1), 19-35

Hater, J.J. \& Bass, B.M. (1988). Superiors' evaluations and subordinates' perceptions of transformational and transactional leadership. Journal of Applied Psychology, 73 (4), 695-702.

Hodson, R. (1999). Management citizenship behavior: A new concept and an empirical test. Social Problems, 46 (3), 460-478.

Ironson, G.H., Smith, P.C., Brannick, M.T., Gibson, W.M. \& Paul, K.B. (1989). Construction of a job in general scale: A comparison of global, composite, and specific measures. Journal of Applied Psychology, 74 (2), 193-200.

Judge, T.A. \& Bono, J.E. (2000). Five-factor model of personality and transformational leadership. Journal of Applied Psychology, 45 (5), 751-765.

Kanungo, R.N. (1982a). Work alienation. An integrative approach. New York: Praeger.

Kanungo, R.N. (1982b). Measurement of job and work involvement. Journal of Applied Psychology, 67 (3), 341-349.

Keller, R.T. (1997). Job involvement and organisational commitment as longitudinal predictors of job performance: A study of scientists and engineers. Journal of Applied Psychology, 82 (4), 539-545.

Knoop, R. (1986). Job involvement: An elusive concept. Psychological Reports, 59, 451-456.

Lease, S.H. (1998). Annual review, 1993-1997: Work attitudes and outcomes. Journal of Vocational Behavior, 53, 154-183. 
Lee, K., Carswell, J.J. \& Allen, N.J. (2000). A meta-analytic review of occupational commitment: Relations with person-and work-related variables. Journal of Applied Psychology, 65 (5), 799-811.

Levin, I. \& Stokes, J.P. (1989). Dispositional approach to job satisfaction: Role of negative affectivity. Journal of Applied Psychology, 74 (5), 752-758.

Lu, L. (1999). Work motivation, job stress and employee wellbeing. Journal of Applied Management Studies, 8 (1), 61.

McGee, G.A. \& Ford, R.C. (1987). Two (or more?) dimensions of organisational commitment: Reexamination of the affective and continuance commitment scales. Journal of Applied Psychology, 72 (4), 538-642.

Meyer, J.P. \& Allen, N.J. (1984). Testing the "side-bet theory" of organisational commitment: Some methodological considerations. Journal of Applied Psychology, 69 (3), 372-378.

Meyer, J.P., Allen, N.J. \& Smith, C.A. (1993). Commitment to organisations and occupations: Extension and test of a threecomponent conceptualization. Journal of Applied Psychology, 78 (4), 538-551.

Morrow, P.C. (1983). Concept redundancy in organisational research: The case of work commitment. Academy of Management Review, 8 (3), 486-500.

Organ, D.W. (1988). Organisational citizenship behavior: The good soldier syndrome. Lexington, MA: Lexington.

Organ, D.W. \& Ryan, K. (1995). A meta-analytic review of attitudinal and dispositional predictors of organisational citizenship behavior. Personnel Psychology, 48 (4), 775-802.

Paullay, I.M., Alliger, G.M. \& Stone-Romero, E.F. (1994). Construct validation of two instruments designed to measure job involvement and work centrality. Journal of Applied Psychology, 79 (2), 224-228.

Posdakoff, P.M. \& MacKenzie, S.B. (1994). Organisational citizenship behaviors and sales unit effectiveness. Journal of Marketing Research, XXXI, 351-363.

Posdakoff, P.M.; Ahearne, M. \& MacKenzie, S.B. (1997). Organisational citizenship behavior and the quantity and quality of work group performance. Journal of Applied Psychology, 82 (2), 262-270.

Posdakoff, P.M., MacKenzie, S.B. \& Bommer, W.H. (1996). Transformational leader behavior and substitutes for leadership as determinants of employee satisfaction, commitment, trust and organisational citizenship behaviors. Journal of Management, 22 (2), 259-289.
Randall, B.D., Dunham, J.A., Grube \& Castaneda, M.B. (1994). Organisational commitment: The utility of an integrative definition. Journal of Applied Psychology, 79 (3), 370-380.

Reichers, A.E. (1985). A review and reconceptualization of organisational commitment. Academy of Management Review, 10 (3), 465-476.

Roodt, G. (1997). Theoretical and empirical linkages between work-related commitment foci. Journal of Industrial Psychology, 23 (2), 6-13.

Schnake, M. \& Dumler, M.P. (1993). The relationship between "traditional" leadership, "super" leadership, and organisational citizenship behavior. Group and Organisational Management, 18 (3), 352-365.

Shore, L.M., Barksdale, K. \& Shore, T.H. (1995). Managerial perceptions of employee commitment to the organisation. Academy of Management Journal, 38 (6), 1593-2016.

Shore, L.M. \& Wayne, S.J. (1993). Commitment and employee behavior: Comparison of affective commitment and continuance commitment with perceived organisational support. Journal of Applied Psychology, 78 (5), 774-780.

Somers, M.J. (1993). A test of the relationship between affective and continuance commitment using non-recursive models. Journal of Occupational and Organisational Psychology, 66 (2), 185-192.

Steel, R.P. \& Rentsch, J.R. (1997). The dispositional model of job attitudes revisited: Findings of a 10-year study. Journal of Applied Psychology, 82 (6), 873-879.

Storm, L. \& Roodt, G. (2002). Die verband tussen organisasiesosialisering en organisasieverbondenheid (The relationship between organisational socialization and organisational commitment). SA Journal of Industrial Psychology, 28 (1), 14-21.

Tepper, B.J. \& Percy, P.M. (1994). Structural validity of the multifactor leadership questionnaire. Educational \& Psychological Measurement, 54 (3), 734-745.

Tracey, J.B. \& Hinkin, T.R. (1998). Transformational leadership or effective managerial practices? Group and Organisational Management, 23 (3), 220-237.

Trott, M.C. \& Windsor, K. (1999). Leadership effectiveness: How do you measure up? Nursing Economics, 17 (3), 127-130.

Van Yperen, N.W. \& van den Berg, A.E. (1999). Towards a better understanding of the link between participation in decisionmaking and organisational citizenship behaviour: A multilevel analysis. Journal of Occupational and Organisational Psychology, 72 (3), 377-392. 